\title{
ADVANTAGES, DISADVANTAGES AND THE PERFORMANCE OF FOREIGN DIRECT INVESTMENT IN THE REPUBLIC OF KOSOVO
} 2008-2019

\author{
Getoar LUBENIQI, PhD. C. (1D1
}

1 Agricultural University-Plovdiv, Faculty of Economics, Department of Economy and Management, getoar.lubeniqi@hotmail.com,

\begin{tabular}{|c|c|}
\hline Article history: & $A b s t r a t$ \\
\hline $\begin{array}{l}\text { Accepted } 11 \text { January } 2020 \\
\text { Available online } 31 \text { April } 2020\end{array}$ & Economic development is an aspiration for every country in the world including Kosovo. Foreign \\
\hline & Direct Investment (FDI) plays a very important role in the economic development of Kosovo which \\
\hline Keywords: & is in the process of transition. For Kosovo, it is essential to have an accelerated pace of economic \\
\hline Republic of Kosovo, & growth, lower unemployment, higher quality of life, lower demographic migration and lower poverty \\
\hline Direct Foreign investments, & rates, thus attracting FDI has a direct and very important role to play. Although Kosovo has a large \\
\hline Business environment, & number of advantages for attracting foreign investment, there are also a number of challenges or \\
\hline Economic Development, & disadvantages that are very evident which negatively impact on current and potential investors in the \\
\hline Doing Business. & future. Based on the data analysis, the overall trend of FDI has declined in recent years, therefore it \\
\hline & $\begin{array}{l}\text { is very important for Kosovo to develop further steps to improve the business climate in Kosovo and } \\
\text { attract foreign investments. }\end{array}$ \\
\hline
\end{tabular}

The purpose of this paper is to analyze the performance of FDI in Kosovo 2008-2019, to analyze the advantages and disadvantages of doing business in Kosovo, to identify where Kosovo stands in terms of doing business and what is new for Kosovo in a way that improve the business environment and attract foreign investment. To achieve this goal of comparative analysis and identification, the integrative review method was used.

\section{Introduction}

Given the fact that Kosovo is currently facing various problems and obstacles that directly affect the slacke of economic development, FDI plays a very important role for Kosovo. Kosovo currently has a general lack of financial insufficiency, while on the other hand there is an urgent need to address the unemployment problem and the socio-economic aspect in general. FDI is very important for the state of Kosovo and plays a key role in many different aspects, such as new technologies, new capital, positive impact on marketing and management as well as western experience plays a very important role, therefore as a result this would help economic growth, generate new jobs, increase exports and improve the deficit market (Shkodra, Xhemili, Badivuku-Pantina 2015, 82).

FDI is closely linked to economic growth in different countries and thus FDI plays a very important role for countries in transition such as Kosovo and this is due to the great need these transition contries have for attracting FDI and exploiting them effeciently in the most strategic sectors of their respective economies (Badivuku-Pantina, Zogjani 2015, 28).

According to Ilia Kristo (2004), FDI represents the takeover of various investment operations and they represent the influx of many organizations that include international investment. FDI has its positive and negative aspects in the host country. The host country should have a close relationship with foreign investors and should value their contribution to the economy of the country concerned. FDI is followed by positive and negative aspects in a given country. Positive aspects consist: 1 . capital formation; 2 . new technologies; 3. geographic and regional development; 4. entrepreneurship and internal competition; 5. employment. Whilst, negative aspects include: 1 . individual dominance; 2. 
technological dependence; 3. economic plan concerns; 4. cultural changes; 5 . avoidance of local government.

The Western Balkans consists of 6 countries: North Macedonia, Kosovo, Albania, Bosnia and Herzegovina, Serbia and Montenegro which have political, economic and social similarities. Western Balkan states, including Kosovo, have many natural and human resources, but are still not being treated seriously by international investors (Jusufi, Lubeniqi 2019, 168). However, the impact of the global financial crisis that reached its peak in 2008 has also been transmitted in the reduction of FDI in the western Balkans including Kosovo, due to the fact that the eurozone countries have been most affected by this crisis and are countries that provide the largest sources of FDI inflows. The emergence of this crisis made these countries face economic hardship and as a result reduced FDI. (Badivuku-Pantina, Alishani 2015, 264)

In October 27, 2015, in Strasbourg, Kosovo signed the Stabilization and Association Agreement. The agreement enables Kosovo to liberalize trade with all European Union (EU) member states, strengthen regional co-operation by aligning its political and economic preferences with EU member states and implement an appropriate institutional framework in order to increase Kosovo's competitiveness. This agreement also includes cooperation between the parties to promote and protect overall investment by focusing on FDI, domestic investment and creating a favorable climate for overall investment, which is very important for Kosovo to revitalize its economic development. (Group for Legal and Political Studies, 2017).

According to WORLD BANK GROUP - Doing Business (2019), Kosovo is ranked 44th in doing business. While according to WORLD BANK - Country Snapshot (2019), Kosovo's mediumterm growth outlook is positive, but the country needs to create a sustainable political environment and create a better business climate by attracting investment. In order to attract FDI, Kosovo should take the following measures: systematic increase of political stability, fight against corruption, increase of constant contacts with the Kosovar diaspora, reduction of bureaucracy, facilitation of administrative procedures, strengthening of the legal environment (Riinvest, 2002)

This paper is organized into five sections. The first section begins with an introduction. The second section is about the advantages of doing business in Kosovo. The third section analyzes the disadvantages of doing business in Kosovo. The fourth section analyzes FDI performance for the period 2008-2019. At the end is the section of conclusions.

\section{The Advantages of Doing Business in}

\section{Kosovo}

Kosovo has a very favorable and strategic position because it is located in the heart of the Balkans. Distance to regional countries places Kosovo as a very attractive place for attracting FDI and Kosovo offers easy access by road, rail and sea ports such as Thessaloniki to Greece: $329 \mathrm{~km}$, Durres to Albania: $262 \mathrm{~km}$ and Bar to Montenegro : $299 \mathrm{~km}$ (Ministry of Trade and Industry [MTI], Kosovo Investment and Enterprise Support Agency [KIESA]). The recent investments of the Republic of Kosovo in highways have positioned Kosovo as a very attractive place for foreign investments, the highways with Albania and Northern Macedonia have positively impacted the reduction of transport time to three hours and one hour respectively. Prishtina International Airport contains regular flights and is connected to almost all international countries.

The workforce which constitute $65 \%$ of the population is considered to be the cheapest in the region, multiethnic country and the knowledge of foreign languages make Kosovo very attractive for foreign direct investment (Group for legal and political studies, 2017).

Kosovo is the youngest population in Europe, with an average age of 30.2 years. This workforce is well-trained and this makes Kosovo attractive to foreign investors. There are a number of aspects that make Kosovo attractive for FDI, noting that Kosovo had consistently an average GDP growth rate of $3.5 \%$ for 2009 2018. This positive performance is also foreseen for 2019 at the rate of $4.4 \%$, while in 2018 GDP increased $4.1 \%$ (Kosovo Reform and Economy Program 2019-2021). Kosovo's economy has continued to increase above the average of the Western Balkans after the global financial crisis. GDP per capita increased from US \$ 1,088 in 2000 to US \$4,108 in 2018. (The World Bank in Kosovo - Country Snapshot, 2019).

Kosovo has dynamically made efforts to stimulate the formal economy and boost investment, therefore in 2015 Kosovo implemented the new fiscal package aimed to promote the formal economy and attracting different investments. This package is also extremely attractive for FDI where Corporate Income Tax of $10 \%$ (MTI - KIESA) is foreseen. In addition, the Law on Strategic Investments that aims to facilitate market access for investors in key sectors has also been ratified: 1 . Energy with infrastructure and Mining; 2. Transport and Telecommunication; 3. Tourism; 4. Processing industry; 5. Agriculture and Food Industry; 6. Health; 7. Industrial and Technological Parks; 8. Wastewater and Waste Management. The Law on Strategic Investments aims to identify priority sectors that affect economic development, contribute to employment growth, the applying new technologies, increase 
exports, reduce trade deficits and increase welfare of citizens in general. (Strategic Investments in the Republic of Kosovo, 2017). In addition, in Kosovo there is a large number of sectors that can attract FDI, a very important sector is Information and Communication Technology (ICT), while on the other hand there is a huge investment potential for the metal extraction and processing industry. Also, the natural potential is rich with: coal, zinc, ores and lead, therefore all these assets make Kosovo very attractive for FDI. (Çollaku, 2018).

\section{The Disadvantages of Doing Business in}

\section{Kosovo}

Although Kosovo has a large number of advantages for attracting foreign investment, there are also a number of challenges or disadvantages that are very evident and which negatively impact on current and potential investors for the future. It is very important for Kosovo to develop further steps to improve the climate of doing business in Kosovo and attract foreign investment. Kosovo is currently very limited in attracting FDI due to poor communication and lack of information sharing with international markets and the international economic environment. Unstable political stability, high corruption, lack of transparency, slow reforms to the business environment, poor perception of foreign investors and citizens of the Kosovo diaspora are all challenges and disadvantages faced by current and potential foreign investors in Kosovo. (Group for Legal and Political Studies, 2017). Kosovo is currently facing a lack of rule of law and this is a very important aspect of Kosovo's position with a bad and unattractive perception for foreign investors (Çollaku, 2018). Kosovo does not stand well in the informal economy either, which according to Southeast European Leadership for Development and Integrity (SELDI), (2016) the informal economy is estimated at $31 \%$ of the GDP.

Group for Legal and Political Studies cooperated with the European Investors Council (EIC), (2017), conducted a study with foreign investors operating in Kosovo, with the aim of identifying foreign investors' perceptions of investments in Kosovo and the climate of doing business in Kosovo. The paper will focus on highlighting only the aspect of disadvantages that respondents have highlighted. A total of 16 investors have been randomly selected from European Union (EU) and European Free Association (EFTA) countries. The survey was conducted during July-September 2016 and the respondents were those investors who started investing after 2000 and after 2005. The disadvantages of the respondents were as follows:

Table 1. Investors perception

\begin{tabular}{|c|c|c|c|}
\hline & Negative & Positive & Neutral \\
\hline Infrastructure & $37.50 \%$ & 0 & $62.50 \%$ \\
\hline Labor-Related Matters & $12.50 \%$ & $12.50 \%$ & $75 \%$ \\
\hline Political Factors & $93.75 \%$ & 0 & $6.25 \%$ \\
\hline Rule of Law & $93.75 \%$ & 0 & $6.25 \%$ \\
\hline Socal Factors & $18.75 \%$ & $37.50 \%$ & $43.75 \%$ \\
\hline Financing & $25 \%$ & $6.25 \%$ & $68.75 \%$ \\
\hline
\end{tabular}

Source: Group for Legal and Political Studies

-Institutional incompetence, weak rule of law, corruptin, weak legislative implementation, frequent legislative changes.

-Lack of incentives, adequate treatment and security for investitors.

-Ambiguous and inconsistent regulations, weak contract enforcement

-Lack of functional administration, incompetent courts, corrupt public procurement, immature guverment

-Market instability, lack of standards, lack of guverment will towards creating favorable environment, bureaucrycy, ethinic tensions

-Clientelism

-Kosova's Image

-Education. 


\section{The Performance of Foreign Direct Investments in the Republic of Kosovo 2008-2019}

Given the positive impact that foreign investments have on the economy, developing countries are interested in attracting FDI. Over the last decade, Kosovo has been maximally committed to attracting FDI by making various reforms to improve the business environment in order to affect economic growth, increase employment and welfare and aim to reduce poverty. Foreign investment during the period 2008-2019 has not been positive. The trend of FDI during this period has steadily declined and this has been due to many factors according to the report (Group for legal and political studies, 2017). The decline in FDI has been a result of high corruption, the lack of rule of law, organized crime, and the unstable political stability facing Kosovo, while on the other hand, the slow process with many problems within the privatization process have had a negative impact on foreign investments. Nevertheles, according to Nadie Ahmeti (2019), political instability has been one of the factors that has adversely affected FDI. However, the impact of the global financial crisis that reached its peak in 2008 has also been transmitted to the reduction of FDI in the western Balkans including Kosovo, as a result of the fact that the eurozone countries have been most affected by this crisis and are countries that provide the largest sources of FDI inflows, then with the emergence of the crisis these countries have faced economic difficulties and as a result FDI has decreased (Badivuku-Pantina, Alishani 2015, 264). The trend of FDI over these years is shown in the table below:

Table 2. Foreign Direct Investment - based on economic activity

Investments' value within the reporting period: in millions of Euros

\begin{tabular}{|c|c|c|c|c|c|c|c|c|c|c|c|c|c|}
\hline Years & हूँ & 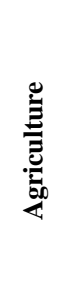 & $\stackrel{\mathscr{g}}{\vec{E}}$ & $\begin{array}{l}\vec{E} \\
\frac{\vec{E}}{E}\end{array}$ & 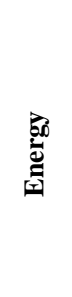 & 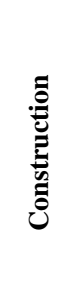 & 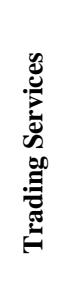 & 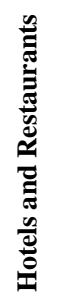 & 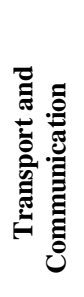 & 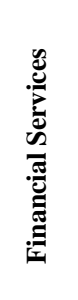 & 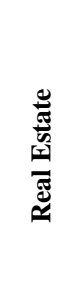 & 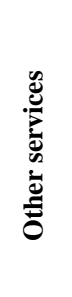 & 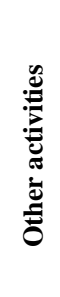 \\
\hline 2008 & 369.9 & 8.5 & $\begin{array}{l}17.4 \\
\end{array}$ & 53.7 & 16.7 & 16.5 & \begin{tabular}{ll|}
10.1 \\
\end{tabular} & 2.1 & 51 & 109.6 & $\begin{array}{l}62.2 \\
\end{array}$ & 2.1 & 23 \\
\hline 2009 & 287.4 & 13.1 & 7 & 57.6 & $\begin{array}{l}8.7 \\
\end{array}$ & 35.5 & 16.2 & 2.4 & 21.9 & 75.3 & 43.9 & 2.7 & 3.2 \\
\hline 2010 & 368.5 & 0.9 & 17.7 & 101.1 & - & 54.2 & 6.8 & - & -15.9 & 39.4 & 75.5 & 1.3 & 87.6 \\
\hline 2011 & 384.4 & 0.6 & $\begin{array}{l}-5.2 \\
\end{array}$ & 46.9 & 0.2 & 133.1 & 11.6 & 0.2 & 29 & 33 & 60.5 & 11.3 & 63.2 \\
\hline 2012 & 229.1 & 0.3 & -25 & 27.4 & 2.2 & 31.1 & 9.3 & 0.5 & 32.4 & 22.4 & 115.7 & 1.8 & 11 \\
\hline 2013 & 280.2 & 0.4 & -14.1 & 11.5 & 48.8 & 17.3 & 14.6 & 0.8 & 51 & 4.4 & 136.1 & 3.3 & 6.2 \\
\hline 2014 & 151.2 & 0.2 & $\begin{array}{l}4.2 \\
\end{array}$ & $\begin{array}{l}-34 \\
\end{array}$ & 13.4 & -19.9 & 8.4 & 0.4 & $\begin{array}{l}-9.1 \\
\end{array}$ & 41.9 & 142.1 & 2.2 & 1.4 \\
\hline 2015 & 308.8 & 1 & -36.9 & 20.7 & 11.9 & 46.3 & 12 & 0 & -6.1 & 64.3 & 189.6 & 4.5 & 1.4 \\
\hline 2016 & 220 & 1.2 & -19.1 & 4.6 & 3.4 & 28.2 & 14.5 & 0.7 & $\begin{array}{l}-9.4 \\
\end{array}$ & 19 & 167.6 & 9.4 & -0.6 \\
\hline 2017 & 255.4 & $\begin{array}{l}-1.3 \\
\end{array}$ & $\begin{array}{l}-4.9 \\
\end{array}$ & 5.7 & $\begin{array}{ll}-1 \\
\end{array}$ & 5 & 10.3 & 0.8 & \begin{tabular}{l|l|}
-7.9 \\
\end{tabular} & 55 & 187.2 & 4.9 & 1.6 \\
\hline 2018 & 272.1 & 0.1 & -2.7 & -16 & 26.2 & 24.8 & 20.2 & 1.8 & -16.6 & 14.5 & 207.5 & 10.3 & 2 \\
\hline 2019 & 229 & 1.4 & $\begin{array}{l}-1.6 \\
\end{array}$ & \begin{tabular}{l|l|}
-4.1 \\
\end{tabular} & 16 & 12.1 & $\begin{array}{l}-8.6 \\
\end{array}$ & 1.1 & 1.7 & 11.2 & 173.8 & $\begin{array}{l}5.9 \\
\end{array}$ & 7.3 \\
\hline
\end{tabular}

Source: Central Bank of Kosovo

According to statistical data analysis, the value of FDI for the reporting period 2008-2019 has decreased.

Based on chronological analysis, if we compare the last three years of the reporting period, the trend of foreign investments has been approximately the same. However, if we rely on the general trend of FDI, the highest amount of investment was in 2008 with 369.9 million Euro invested, while the lowest amount of foreign investment was in 2014 with 151.2 million Euro. Real Estate, Financial Services and Construction are among the most important sectors where the highest value of investments by foreign investors is achieved. According to the chronological analysis, in the real estate sector from 2008 to 2019 , the value of investments has been increasing year after year. In the Financial

Services sector as the second most attractive sector, the value of investments was large but does not reflect any trend of progressive growth, however the trend of investments in this sector has been the same. While in the Construction sector as the third most important sector for foreign investments, the lowest value of investments was in 2014, while the highest in 2011, but as a general conclusion the trend of investments in the construction sector has been the same.

Foreign direct investment has consistently been driven by many international countries that have directed capital flows into 
Kosovo. The country of origin of these investments varies in the general trend. The following table shows the FDI origin according to the analysis for the period 2008-2019:

Table 3. Direct Investment - by Countries

The Value of investments within the reporting period, in millions of Euros

\begin{tabular}{|c|c|c|c|c|c|c|c|c|c|}
\hline Years & 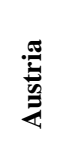 & 胥 & 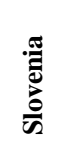 & 光 & 胥 & $\underset{\Xi}{\stackrel{d}{\Xi}}$ & 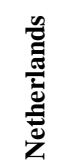 & $\underset{\mathscr{D}}{\overparen{\Omega}}$ & 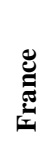 \\
\hline 2008 & 51.3 & 44 & 44.3 & 36.6 & 32.1 & 23.8 & 25.9 & 4.8 & 3.5 \\
\hline 2009 & 15.5 & 75.2 & 50.8 & 6.2 & 22.7 & 14.5 & 23.1 & 11.8 & 6 \\
\hline 2010 & 21.1 & 91.5 & 34 & 38.9 & 35.1 & 4.9 & 17.2 & 12.6 & 3.8 \\
\hline 2011 & 19.6 & 66.6 & 16.2 & 80.1 & 30.9 & 34.7 & 4.7 & 14.3 & 0.2 \\
\hline 2012 & 0.2 & 49.2 & 8 & 14.3 & 39.7 & 62.7 & -26.7 & 8.5 & 6.9 \\
\hline 2013 & 10.7 & 21.7 & 7 & 10.7 & 41.7 & 88.6 & -0.1 & 12.7 & 3.8 \\
\hline 2014 & 30.3 & 39.4 & -9.4 & -39.5 & 38.2 & 20 & -7.8 & 14.7 & 3.3 \\
\hline 2015 & 33.5 & 45.3 & 5.6 & 26.6 & 72.9 & 55.4 & -36.4 & 25 & 3.2 \\
\hline 2016 & 9.9 & 25.7 & -4.5 & 13.6 & 61.8 & 42.7 & -23.1 & 23 & 2.8 \\
\hline 2017 & 20.3 & 55.9 & 1.2 & 27 & 50.6 & 29.5 & -14.1 & 20.3 & 3.6 \\
\hline 2018 & 11.2 & 60.3 & -8.7 & 57.4 & 71 & 12.2 & -39.7 & 35.5 & 5.6 \\
\hline 2019 & 3.2 & 57.4 & 10.3 & -10.3 & 39.5 & 4.7 & -4.1 & 28.6 & 2.8 \\
\hline
\end{tabular}

Source: Central Bank of Kosovo

Based to chronological data analysis, the greatest investing countries are Germany and Switzerland, followed by Turkey and the UK. Over the years, the flow of investment originating from Germany and Switzerland has been increasing, while it is interesting to note that the Netherlands has had a negative investment trend since 2012. It is very important to note if we focus on the United States of America (US) that the overall trend of investment is constantly increasing. The value of the largest investments from Germany was in 2010 with 91.5 million euros, while the lowest value was in 2013 with 21.7 million euros. On the other hand, if we look Switzerland, the highest value of investment was $€ 72.9$ million in 2015, while the lowest value of investment was $€ 22.7$ million in 2009 .

\section{Conclusion}

Based on the data analysis, the performance and trend of foreign direct investment has been negative, over the years the trend of foreign direct investment has declined. According to the comparative period data analysis, the most important sectors to invest by foreign investors have not changed. The most important sectors that have absorbed most investments remain Real Estate, Financial Services and Construction. However, all three sectors have declined since 2017, and this is an indication that the market is saturating. According to data analysis, Germany, Switzerland and Turkey remain the leading countries with most investments during this decade. The high level of investment from Turkey is directly linked to the privatization of electricity distribution and investment in the new airport terminal. While the other two countries that have been leading the FDI, Germany and Switzerland, the investment flow is also due to the concentration of the Kosovar diaspora in these countries. FDI remains vital to Kosovo's economy, therefore the Kosovo government needs to develop a concrete strategy and plan for attracting and protecting foreign investors. The Government of Kosovo should dynamically and as quickly as possible begin the process of reforming the business environment, aiming to improve the ranking and doing business at the national level in a higher and more positive order. Kosovo has many advantages and natural resources for attracting foreign investors, but on the other hand Kosovo lacks specific FDI attaractive policies. Kosovo should start the fight against corruption and organized crime as soon as as possible in order to become attractive for FDI. If Kosovo institutions do not address the fight against corruption as the first and most important step, then Kosovo will not be able to improve the image for attracting FDI. In order to achieve a better ranking of doing business in Kosovo and to gain the attraction and positive perception of Foreign Investors, it is crucial that Kosovo succeeds in overcoming a large number of long term challenges that it faces, therefore it is very important for Kosovo to achieve political stability, combat and reduce the informal economy, have reliable electricity supply, strengthen the rule of law, and achieve normalization of relations with Serbia. On the other hand, it is very important to improve the education system with the aim of improving and enhancing the quality of the workforce, matching them with the needs of employers and the needs of the market in general. 
Kosovo institutions should have the support of everyone, including every citizen of Kosovo in order to improve the environment and climate of doing business. Everyone should bare in mind that without FDI, Kosovo will not be able to have economic development in general.

\section{References}

1. Ahmeti N. (2019), "Foreign investments decline in Kosovo" [Online]. Available from: https://www.evropaelire.org/a/investimet-e-huaja-kosove/29978901.html, [Accessed 13 January , 2019]

2. Badivuku-Pantina M. \& Alishani A., (2015), "The History of Financial Crises - Global Financial Crisis", Prishtina: Artini Publishing.

3. Badivuku-Pantina M. and Zogjani J., (2015), "The Role and Impact of Remittances on the Economic Growth Kosovo Case Study" ILIRIA International Review, Vol 5, No 2 (2015) pg. 28. https://doi.org/10.21113/iir.v4i2.32

4. Central Bank of the Republic of Kosovo - Monthly Statistical Bulletin, (2019), [Online]. Available from: https://bqk-

kos.org/repository/docs/2018/BQK_BMS_219_al.pdf,

[Accessed 16 January , 2019]

5. Çollaku P., (2018), "Kosovo's problem with foreign direct investment" [Online]. Available from: https://wiiw.ac.at/kosovo-s-problem-with-foreign-directinvestment-n-339.html, [Accessed 03 February , 2019] 6. Group for legal and political studies, (2017), "How 'friendly' is Kosovo for Foreign Direct Investments: A Policy Review of Gaps from a Regional Market Perspective" Prishtina.

7. Jusufi G. and Lubeniqi G., (2019), "An Overview of Doing Business in Western Balkan: The Analysis of Advantages of Doing Business in Kosovo and North Macedonia" ILIRIA International Review, Vol 9, No 2 (2019) pg. 168. https://doi.org/10.21113/iir.v9i2.512

8. Kristo I., (2004), "International Business ", Tirana: Pegi, 2nd Edition.

9. Ministry of trade and Industry [MTI], Kosovo Investment and enterprise support agency - [KIESA] Republic of Kosovo, "Reasons to Invest" [Online]. Available from: https://kiesa.rksgov.net/page.aspx?id=1,15, [Accessed 05 January, 2019] 10. Ministry of European Integration - Republic of Kosovo, "Stabilisation and Association Agreement", [Online]. Available from: https://www.meiks.net/en/stabilization-association-brprocess-, [Accessed 14 January, 2019]
11. OFFICIAL GAZETTE OF THE REPUBLIC OF KOSOVA, (2017), "LAW No. 05/L-079 ON STRATEGIC INVESTMENTS IN THE REPUBLIC OF KOSOVO" Prishtina, [Online]. Available from: https://mzheks.net/repository/docs/LAW_NO._05_L079__ON_STRA TEGIC_INVESTMENTS_IN_THE_REPUBLIC_OF_KO SOVO.pdf, [Accessed 25 January, 2019]

12. Kosovo Economic Reform Program 2019-2021 Republic of Kosovo, [Online]. Available from:https://mf.rks-gov.net/desk/inc/media/85F252D8-

FEAE-46BF-8CBDF110BBA0B8EE.pdf, [Accessed 10 January, 2019]

13. Riinvest. \& Cipe., (2002), "FOREIGN DIRECT INVESTMENTS IN KOSOVO - Economic Policy, Environment and Promotion Strategy".

14. Shkodra N. Xhemili N. and Badivuku-Pantina M., (2015), "Challenges and Problems in the Kosovo Reality Related to Foreign Direct Investment" ILIRIA International Review, Vol 5, No 1 (2015) pg. 82. https://doi.org/10.21113/iir.v5i1.6

15. Southeast European leadership for development and integrity [SELDI], (2016), "HIDDEN ECONOMY IN SOUTHEAST EUROPE: MONITORING AND POLICY IMPLICATIONS FOR GOOD GOVERNANCE" [Online]. Available from: https://www.cin.ba/wpcontent/uploads/2017/02/Policy-Brief-Hidden-

Economy.pdf, [Accessed 17 January , 2019]

16. WORLD BANK - Country Snapshot, (2019), “An overview of the World Bank's work in Kosovo”, Prishtina. 17. WORLD BANK GROUP, (2019), “A World Bank Group Flagship Report: Doing Business-Training for Reform", 16th edition. 